\title{
Assessing Quantitative Criteria for Characterization of Quality Categories for Grafted Watermelon Seedlings
}

\author{
Filippos Bantis ${ }^{1}$, Athanasios Koukounaras ${ }^{1, *} \mathbb{0}$, Anastasios Siomos ${ }^{1}$, Georgios Menexes ${ }^{1}$, \\ Christodoulos Dangitsis ${ }^{2}$ and Damianos Kintzonidis ${ }^{2}$ \\ 1 School of Agriculture, Aristotle University of Thessaloniki, 54124 Thessaloniki, Greece; \\ fbanths@gmail.com (F.B.); siomos@agro.auth.gr (A.S.); gmenexes@agro.auth.gr (G.M.) \\ 2 Agris S.A., Kleidi, 59300 Imathia, Greece; cdaggitsis@agris.gr (C.D.); damianos@agris.gr (D.K.) \\ * Correspondence: thankou@agro.auth.gr; Tel.: +30-2310-994123
}

Received: 26 December 2018; Accepted: 28 January 2019; Published: 2 February 2019

\begin{abstract}
Vegetable grafting is a practice employed worldwide since it helps prevent biotic and abiotic disorders, and watermelon is one of the most important species grafted. The objective of this study was to set critical limits for the characterization of quality categories for grafted watermelon seedlings. Specifically, watermelon (scion) seedlings were grafted onto squash (rootstock) seedlings, moved into a healing chamber for 7 days, and then transferred into a greenhouse for seven more days. At 7 and 14 days after grafting, experienced personnel assessed grafted seedling quality by categorizing them. The categories derived were Optimum and Acceptable for both time intervals, plus Not acceptable at 14 days after grafting. Optimum seedlings showed greater leaf area, and shoot and root fresh and dry weights at both time intervals. Moreover, they had greater stem diameter, root-to-shoot ratio, shoot dry weight-to-length ratio and Dickson's quality index compared to the other category at 14 days after grafting. Therefore, Optimum seedlings would likely develop into marketable plants of high quality, with better establishment in the field. Not acceptable seedlings showed considerably inferior development, while Acceptable seedlings were between the other categories, but were still marketable.
\end{abstract}

Keywords: Citrullus lanatus; vegetable grafting; optimal production; marketable seedlings; quality indicators

\section{Introduction}

The use of grafting for vegetable seedlings is a well-established practice worldwide [1-3]. The important advantage of using grafted seedlings to prevent significant crop loss due to biotic $[3,4]$ and abiotic [5,6] factors (soil-borne diseases, salinity, low temperatures, etc.), as well as the reduction of the use of agrochemical products, provide grafting as an environmentally-friendly practice [3]. Applications of grafting mainly focus on species of the Cucurbitaceae and Solanaceae families, particularly watermelon and tomato, respectively [2,7]. In Greece the use of grafted watermelon seedlings is almost $99 \%$ of growers using low tunnel protected cultivation in order to achieve early yield.

To enjoy the advantages of grafting, use of high quality grafted seedlings is a prerequisite. As a result, a rapid development and expansion of a vegetable nursery industry is in progress. Successful grafting requires good connection between the rootstock and the scion for healthy uniform growth and development of the grafted plants [8]. The most important stage for seedling evaluation for the grower is at the time of purchase and transplanting to avoid possibly negative results during subsequent cultivation. However, the definition of what constitutes a high-quality seedling is a very complicated issue [8]. 
Generally, high-quality seedlings could be defined as plants uniform in size and traits, proper size or height with a thick healthy stem with large thick leaves, a well-developed root system, good root-to-shoot ratio, and a good ratio of shoot dry weight divided by shoot length $[3,8]$. However, most of the above characteristics could be suitable for some species such as tomatoes, peppers, and eggplants, but could be adapted for the cucurbits [3]. Moreover, most seedling quality parameters have been qualitatively determined by experienced personnel. Therefore, it is critical to define quantitative parameters that could be easily and objectively applied by anyone in this chain (industry, grower, etc.).

Therefore, the aim of this study was to set critical limits for objective measurements of grafted watermelon seedling quality categories as well as to suggest the most accurate and convenient among them for application by the industry and growers. Evaluations were conducted at 7 and 14 days after grafting. Grafted watermelon seedlings exit the healing chamber at 7 days after grafting and therefore quality assessment at that time is essential for possible later research. By 14 days, seedlings are considered "final product" and therefore quality evaluation at that time is valuable to assess the product marketability.

\section{Materials and Methods}

\subsection{Plant Material}

The experiments were conducted in the facilities of Agris S.A. in Kleidi, Imathia, Greece. All measurements were executed at Aristotle University of Thessaloniki, Greece. During the experiment, standard commercial practices were applied.

Watermelon (scion-Citrullus lanatus) "Celine" (HM. Clause SA, Portes-Les-Valence, France) and squash (rootstock-Cucurbita moschata) "TZ-148" (HM. Clause SA, Portes-Les-Valence, France) were used for the production of grafted seedlings. Watermelon seeds were sown in plastic 171-cell plug trays, while squash seeds were sown in plastic 128-cell plug trays (both types: $67 \times 33 \mathrm{~cm}$, G.K. Rizakos S.A., Lamia, Greece). Both plug tray types were filled with a 5:1:2 mixture of peat, perlite, and vermiculite.

\subsection{Germination, Grafting, Healing, and Acclimatization}

Following planting, the plug trays of scions and rootstocks were moved into a growth chamber $\left(25^{\circ} \mathrm{C}, 95-98 \%\right.$ relative humidity $\left.(\mathrm{RH})\right)$ until germination. Watermelon and squash germinated after 72 and $48 \mathrm{~h}$, respectively, and afterwards they were moved to a glass greenhouse for 9 (scion) and 10 (rootstock) days at a $21.5^{\circ} \mathrm{C}$ minimum night temperature for both species, and $100 \pm 10 \mu \mathrm{mol}$ $\mathrm{m}^{-2} \mathrm{~s}^{-1}$ photosynthetic photon flux density (PPFD) emitted by high-pressure sodium (HPS) lamps (MASTER GreenPower 600 W, 400 V E40, Philips Lighting, Eindhoven, The Netherlands) with an $18 \mathrm{~h}$ photoperiod only for watermelon. The natural light photoperiod during the experiment was $12.5 \mathrm{~h}$ from sunrise to sunset. Supplemental lighting is commonly practiced for the production of watermelon seedlings in order to achieve high quality product. On the other hand squash seedlings have adequate development under natural light conditions and no supplemental lighting is employed.

Grafting was performed with the "splice grafting" technique, 12 days after sowing. Using a razor blade, the scion was diagonally cut just below the cotyledons while the rootstock was diagonally cut on the cotyledon level leaving only one cotyledon. The rootstock was also cut just above ground level, which is a commonly practiced technique for cucurbit rootstocks in order to achieve increased grafting efficiency [9]. Afterwards, the grafted seedlings were placed in polystyrene 72-cell plug trays $(50 \times 30 \mathrm{~cm}$, G.K. Rizakos S.A., Lamia, Greece) filled with a 3:1:1 mixture of peat, perlite, and vermiculite. Grafting was performed by experienced personnel to minimize critical errors.

Following grafting, healing and acclimatization of grafted seedlings was achieved during 7 days in a growth chamber at $25^{\circ} \mathrm{C}$, recirculating air, $45 \mu \mathrm{mol} \mathrm{m} \mathrm{m}^{-2} \mathrm{~s}^{-1}$ PPFD emitted by fluorescent tubes (Fluora 58W, Osram, GmbH, Munich, Germany) for an $18 \mathrm{~h}$ photoperiod, and $\mathrm{RH}$ of $98 \%$ for days $1-4,93 \%$ for day 5 , and $89 \%$ for days 6 and 7 . $\mathrm{RH}$ was high at the beginning of healing in order to prevent leaf dehydration and it was gradually decreased in order for the seedlings to get acclimated to 
lower RH conditions. The growth conditions were monitored using a climate control system (Priva SA, De Lier, The Netherlands).

After 7 days in the healing chamber the grafted seedlings were placed in a glass greenhouse $\left(21.5^{\circ} \mathrm{C}\right.$ minimum night temperature, $60 \pm 10 \mu \mathrm{mol} \mathrm{m}{ }^{-2} \mathrm{~s}^{-1}$ PPFD emitted by HPS lamps for an $18 \mathrm{~h}$ photoperiod). The high RH was applied to prevent leaf dehydration due to water loss.

\subsection{Quality Categorizing and Measurements}

Seedling quality categorizing, sampling and measurements were conducted at two times, 7 and 14 days after grafting. Experienced personnel categorized quality. The quality categories are listed in Table 1. Critical parameters for categorizing seedling quality were true leaf and cotyledon area, cotyledon color, and root system development (personal communication with Agris S.A., Kleidi, Imathia, Greece). In total, 50 seedlings per category were sampled and the number of samples was equally distributed throughout the three periods of production

Table 1. Seedling quality categories derived seven and 14 days after grafting of watermelon seedlings.

\begin{tabular}{ccc}
\hline Days after Grafting & Quality Categories & Marketable \\
\hline \multirow{2}{*}{7} & Optimum & Yes \\
& Acceptable & Yes \\
\hline \multirow{2}{*}{14} & Optimum & Yes \\
& Acceptable & Yes \\
& Not Acceptable & No \\
\hline
\end{tabular}

A digital caliper (Powerfix, Milomex, Pulloxhill, UK) was used to measure shoot height, stem diameter (about $1 \mathrm{~cm}$ above the substrate surface), and thickness of true leaves, scion cotyledons or rootstock cotyledons. Leaf area of true leaves, scion cotyledons or rootstock cotyledons were measured using a leaf area meter (LI-3000C, LI-COR Biosciences, Lincoln, NE, USA). Fresh and dry weights of shoots (stem and leaves) and roots were determined. Dry weights were obtained after three days of drying in an oven. Moreover, root-to-shoot (R/S) dry weight ratio, shoot dry weight-to-length (DW/L) ratio, and Dickson's quality index (DQI) were estimated. DQI was calculated as follows [10]:

$$
\text { Quality index }=\frac{\text { Seedling total dry weight }(\mathrm{g})}{\frac{\text { Height }(\mathrm{mm})}{\text { Stem diameter }(\mathrm{mm})}+\frac{\text { Shoot dry weight }(\mathrm{g})}{\text { Root dry weight }(\mathrm{g})}}
$$

Relative chlorophyll content was measured using a portable chlorophyll meter (CCM-200 plus, Opti-Sciences, USA). Maximum quantum yield of primary photochemistry, variable to maximal fluorescence of dark-adapted leaves $\left(\mathrm{F}_{\mathrm{v}} / \mathrm{F}_{\mathrm{m}}\right)$, was measured with a fluorometer (Pocket-PEA, Hansatech Instruments, Norflock, UK). Finally, the color of true leaves, scion cotyledons, and rootstock cotyledons was characterized using the colorimetric coordinates lightness $\left(\mathrm{L}^{*}\right)$, Hue $\left(\mathrm{h}^{\circ}\right)$, Chroma $\left(\mathrm{C}^{*}\right)$, $a^{*} / b^{*}\left(a^{*}\right.$ : red/green coordinate; $b^{*}$ : yellow/blue coordinate), and Hue $\left(h^{\circ}\right)$ obtained from a digital colorimeter (CR-400 Chroma Meter, Konica Minolta Inc., Tokyo, Japan) according to McGuire. [11].

\subsection{Statistical Analysis}

Statistical analysis was performed using IBM SPSS software (SPSS 23.0, IBM Corp., Armonk, NY, USA). Data measured at 7 days after grafting were analyzed using a t-test $(P \leq 0.05)$, since at that time point the seedlings were grouped into only two quality categories (Optimum and Acceptable). Data measured at 14 days after grafting were analyzed within the methodological frame of one-way analysis of variance (ANOVA), since at that time point the seedlings were grouped at three quality categories (Optimum, Acceptable and not Acceptable). In this case, mean comparisons were conducted using the Scott-Knott procedure [12], at a significance level of $\alpha=0.05$, using the StatsDirect v.2.8.0. statistical software (StatsDirect, Ltd., Grantchester, Cambridge, UK). The choice of the Scott-Knott 
method was based on its important and unique characteristic that does not present any overlapping in its grouping results. The above is critical in order to obtain quality indices that segregate the different quality categories and, therefore, overlapping results between groups must not occur.

\section{Results}

Seven days after grafting, shoots of Optimum seedlings were significantly longer than Acceptable ones (Table 2). However, stem diameter, shoot DW/L ratio, DQI and thickness of leaves and cotyledons (both scion and rootstock) did not show any differences between Optimum and Acceptable seedlings. Relative chlorophyll content of true leaves and cotyledons, as well as $\mathrm{F}_{\mathrm{v}} / \mathrm{F}_{\mathrm{m}}$ were also similar in the two quality categories tested (Table 2). Colorimetric parameters of true leaves also did not show differences between the two categories, while scion and rootstock cotyledons showed significant differences in parameters such as lightness $\left(\mathrm{L}^{*}\right)$, Hue $\left(\mathrm{h}^{\circ}\right), \mathrm{a}^{*} / \mathrm{b}^{*}\left(\mathrm{a}^{*}\right.$ : red/green coordinate; $\mathrm{b}^{*}$ : yellow/blue coordinate), and $h^{\circ}$ (Table 3 ). Moreover, Optimum seedlings developed significantly greater true leaves and scion cotyledons compared to the Acceptable ones, while no differences were observed in rootstock cotyledons (Figure 1A). Similarly, fresh and dry weight production of shoots and roots were significantly greater for Optimum compared to Acceptable characterized seedlings (Figure 2A,B). However, R/S ratio did not exhibit any significant differences between the different categories (Figure 2C).

Table 2. Morphological and developmental parameters of grafted watermelon seedlings from two quality categories 7 days after grafting.

\begin{tabular}{|c|c|c|c|}
\hline \multirow{2}{*}{\multicolumn{2}{|c|}{ Parameters }} & \multicolumn{2}{|c|}{ Quality Categories } \\
\hline & & Optimum & Acceptable \\
\hline \multirow{5}{*}{\multicolumn{2}{|c|}{$\begin{array}{c}\text { Height }(\mathrm{mm}) \\
\text { Stem diameter }(\mathrm{mm}) \\
\mathrm{DW} / \mathrm{L}^{\mathrm{z}} \\
\mathrm{DQI} \\
\mathrm{F}_{\mathrm{v}} / \mathrm{F}_{\mathrm{m}}\end{array}$}} & $57.82 \pm 1.14 \mathrm{a}^{\mathrm{y}}$ & $47.38 \pm 1.03 \mathrm{~b}$ \\
\hline & & $4.34 \pm 0.04 \mathrm{a}$ & $4.23 \pm 0.05 \mathrm{a}$ \\
\hline & & $0.004 \pm<0.001 \mathrm{a}$ & $0.004 \pm<0.001 \mathrm{a}$ \\
\hline & & $0.012 \pm<0.001 \mathrm{a}$ & $0.012 \pm 0.001 \mathrm{a}$ \\
\hline & & $0.82 \pm<0.01 \mathrm{a}$ & $0.82 \pm<0.01 \mathrm{a}$ \\
\hline \multirow{3}{*}{ Thickness (mm) } & True leaf & $0.62 \pm 0.02 \mathrm{a}$ & $0.59 \pm 0.02 \mathrm{a}$ \\
\hline & Scion cot. & $0.69 \pm 0.01 \mathrm{a}$ & $0.69 \pm 0.01 \mathrm{a}$ \\
\hline & Roots. cot. & $1.20 \pm 0.03 \mathrm{a}$ & $1.15 \pm 0.03 \mathrm{a}$ \\
\hline \multirow{3}{*}{ Relative chl. content } & True leaf & $27.17 \pm 1.26 \mathrm{a}$ & $29.14 \pm 1.04 \mathrm{a}$ \\
\hline & Scion cot. & $44.25 \pm 1.38 \mathrm{a}$ & $43.37 \pm 1.22 \mathrm{a}$ \\
\hline & Roots. cot. & $56.50 \pm 1.88 \mathrm{a}$ & $57.16 \pm 2.31 \mathrm{a}$ \\
\hline
\end{tabular}

${ }^{\mathrm{z}}$ shoot dry weight-to-length ratio; DQI: Dickson's quality index; $\mathrm{F}_{\mathrm{v}} / \mathrm{F}_{\mathrm{m}}$ : maximum quantum yield of primary photochemistry of a dark-adapted leaf; ${ }^{y}$ Mean values $( \pm S E)(n=50)$, within a row, followed by different letters are significantly different by t-test $(P \leq 0.05)$.

Table 3. Colorimetric parameters of grafted watermelon seedlings from two quality categories 7 days after grafting.

\begin{tabular}{cccc}
\hline \multirow{2}{*}{ Plant Tissue } & \multirow{2}{*}{ Colorimetric Parameters } & \multicolumn{2}{c}{ Quality Categories } \\
\cline { 2 - 4 } & & Optimum & Acceptable \\
\hline \multirow{3}{*}{ True leaves } & $\mathrm{L}^{* \mathrm{z}}$ & $41.75 \pm 1.39 \mathrm{a} \mathrm{y}$ & $42.30 \pm 1.96 \mathrm{a}$ \\
& $\mathrm{C}^{*}$ & $24.76 \pm 4.08 \mathrm{a}$ & $24.18 \pm 3.69 \mathrm{a}$ \\
& $\mathrm{h}^{\circ}$ & $129.05 \pm 1.64 \mathrm{a}$ & $128.32 \pm 1.62 \mathrm{a}$ \\
Scion cotyledons & $\mathrm{a}^{*} / \mathrm{b}^{*}$ & $-0.81 \pm 0.05 \mathrm{a}$ & $-0.79 \pm 0.05 \mathrm{a}$ \\
\hline \multirow{3}{*}{ Rootstock cotyledons } & $\mathrm{L}^{*}$ & $42.85 \pm 1.53 \mathrm{~b}$ & $44.12 \pm 2.11 \mathrm{a}$ \\
& $\mathrm{C}^{*}$ & $20.42 \pm 2.31 \mathrm{a}$ & $20.61 \pm 3.15 \mathrm{a}$ \\
& $\mathrm{h}^{\circ}$ & $128.05 \pm 1.21 \mathrm{a}$ & $126.54 \pm 1.98 \mathrm{~b}$ \\
& $\mathrm{a}^{*} / \mathrm{b}^{*}$ & $-0.78 \pm 0.03 \mathrm{~b}$ & $-0.74 \pm 0.05 \mathrm{a}$ \\
\hline & $\mathrm{L}^{*}$ & $39.32 \pm 1.87 \mathrm{a}$ & $39.87 \pm 2.00 \mathrm{a}$ \\
& $\mathrm{C}^{*}$ & $19.66 \pm 1.79 \mathrm{a}$ & $19.69 \pm 2.54 \mathrm{a}$ \\
& $\mathrm{h}^{\circ}$ & $130.07 \pm 1.11 \mathrm{a}$ & $129.26 \pm 1.68 \mathrm{~b}$ \\
& $\mathrm{a}^{*} / \mathrm{b}^{*}$ & $-0.84 \pm 0.03 \mathrm{a}$ & $-0.82 \pm 0.05 \mathrm{a}$ \\
\hline
\end{tabular}

${ }^{\mathrm{z}}$ lightness; $\mathrm{C}^{*}$ : chroma; $\mathrm{h}^{\circ}$ : hue angle; $\mathrm{a}^{*}$ : red/green coordinate; $\mathrm{b}^{*}$ : yellow/blue coordinate; ${ }^{\mathrm{y}}$ Mean values $( \pm \mathrm{SE})$ $(\mathrm{n}=50)$, within a row, followed by different letters are significantly different by $\mathrm{t}$-test $(P \leq 0.05)$. 
Quite similar results were obtained between the quality categories at 14 days after grafting. Specifically, shoot height was significantly greater for Optimum seedlings compared to Acceptable ones, while shoot DW/L ratio was significantly greater for the two marketable categories compared to Not Acceptable seedlings. Stem diameter and DQI were greater for Optimum seedlings compared to the other categories. Nevertheless, thickness of leaves and cotyledons (both scion and rootstock) were similar for all categories. Relative chlorophyll content and $\mathrm{F}_{\mathrm{v}} / \mathrm{F}_{\mathrm{m}}$ were not different between the three quality categories, similar to the 7 day measurements (Table 4). However, differences between the three categories were observed in colour, particularly parameters such as $\mathrm{h}^{\circ}$ and $\mathrm{a}^{*} / \mathrm{b}^{*}$ for the true leaf, and $\mathrm{C}^{*}, \mathrm{~L}^{*}, \mathrm{~h}^{\circ}$, and $\mathrm{a}^{*} / \mathrm{b}^{*}$ for rootstock cotyledons (Table 5). At 7 days after grafting, Optimum scion cotyledons had a darker (lower $\mathrm{L}^{*}$ ) and greener (lower $\mathrm{a}^{*} / \mathrm{b}^{*}$ ) color compared to Acceptable seedlings. At 14 days after grafting, scion cotyledons did not show any color differences but rootstock cotyledons categorized as Optimum had darker (lower $\mathrm{L}^{*}$ ) and greener (lower $\mathrm{a}^{*} / \mathrm{b}^{*}$ ) color compared to the rest of the quality categories. True leaves of Optimum seedlings had significantly greater area compared to the other categories, but scion and rootstock leaf area were not different (Figure 1B). Moreover, fresh and dry biomass of shoots and roots, as well as R/S ratio were significantly greater for Optimum seedlings compared to the other categories (Figure 2D-F).
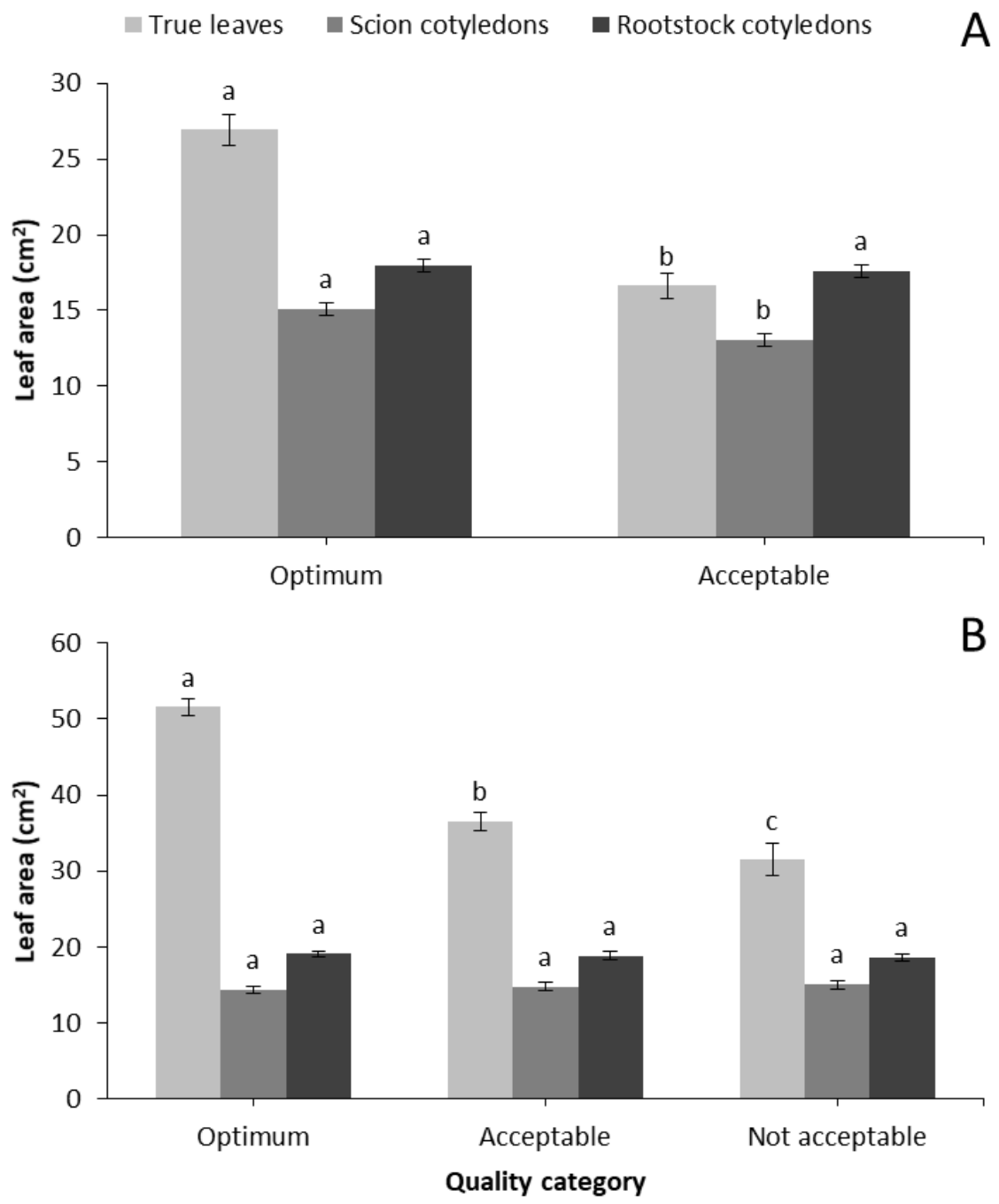

Figure 1. Leaf area of true leaves, scion cotyledons and rootstock cotyledons of grafted watermelon seedlings from the quality categories derived 7 days (A) or 14 days (B) after grafting. Each data point is a mean value \pm standard error (SE) of the mean $(n=50)$. Bars of the same color (same tissue type) across categories with different letters are significantly different $(P \leq 0.05)$ according to the results of the t-test (A) or the Scott-Knott method (B). 

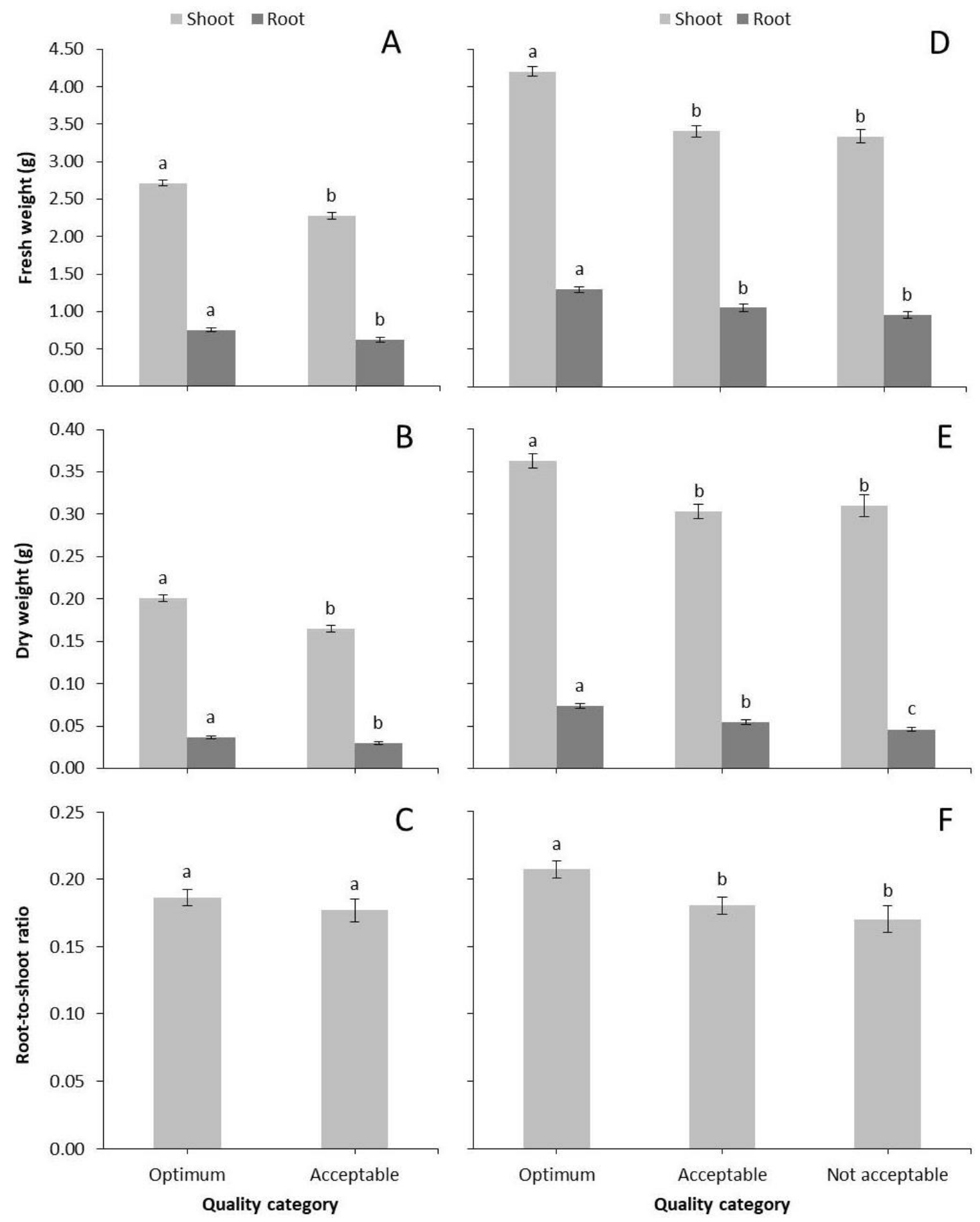

Figure 2. Fresh weight (A) and dry weight (B) of shoots and roots, and root-to-shoot ratio (C) of grafted watermelon seedlings from the quality categories derived 7 days after grafting. Fresh weight (D) and dry weight (E) of shoots and roots, and root-to-shoot ratio (F) of grafted watermelon seedlings from the quality categories derived 14 days after grafting. Each data point is a mean value of 50 observations. Error bars correspond to the standard error (SE) of the mean. Bars of the same colour (same tissue type) across categories followed by different letters are significantly different $(P \leq 0.05)$ according to the results of the t-test $(\mathbf{A}-\mathbf{C})$ or the Scott-Knott method (D-F). 
Table 4. Morphological and developmental parameters of grafted watermelon seedlings from two quality categories 14 days after grafting.

\begin{tabular}{|c|c|c|c|c|}
\hline \multirow{2}{*}{\multicolumn{2}{|c|}{ Parameters }} & \multicolumn{3}{|c|}{ Quality Categories } \\
\hline & & Optimum & Acceptable & Not Acceptable \\
\hline \multicolumn{2}{|c|}{ Height $(\mathrm{mm})$} & $59.10 \pm 1.19 \mathrm{a}^{\mathrm{y}}$ & $52.00 \pm 1.20 \mathrm{~b}$ & $56.80 \pm 1.59 \mathrm{a}$ \\
\hline \multicolumn{2}{|c|}{ Stem diameter (mm) } & $4.65 \pm 0.05 \mathrm{a}$ & $4.49 \pm 0.07 \mathrm{~b}$ & $4.35 \pm 0.05 c$ \\
\hline \multicolumn{2}{|c|}{$\mathrm{DW} / \mathrm{L}^{\mathrm{z}}$} & $0.006 \pm<0.001 \mathrm{a}$ & $0.006 \pm<0.001 \mathrm{a}$ & $0.005 \pm<0.001 \mathrm{~b}$ \\
\hline \multicolumn{2}{|c|}{ DQI } & $0.025 \pm 0.001 \mathrm{a}$ & $0.021 \pm 0.001 \mathrm{~b}$ & $0.018 \pm 0.001 \mathrm{c}$ \\
\hline \multicolumn{2}{|c|}{$\mathrm{F}_{\mathrm{v}} / \mathrm{F}_{\mathrm{m}}$} & $0.84 \pm<0.01 \mathrm{a}$ & $0.84 \pm<0.01 \mathrm{a}$ & $0.84 \pm<0.01 \mathrm{a}$ \\
\hline \multirow{3}{*}{ Thickness (mm) } & True leaf & $0.69 \pm 0.03 \mathrm{a}$ & $0.62 \pm 0.02 \mathrm{a}$ & $0.64 \pm 0.02 \mathrm{a}$ \\
\hline & Scion cot. & $0.72 \pm 0.01 \mathrm{a}$ & $0.73 \pm 0.01 \mathrm{a}$ & $0.74 \pm 0.01 \mathrm{a}$ \\
\hline & Roots. cot. & $1.17 \pm 0.03 \mathrm{a}$ & $1.12 \pm 0.02 \mathrm{a}$ & $1.18 \pm 0.03 \mathrm{a}$ \\
\hline \multirow{3}{*}{$\begin{array}{l}\text { Relative chl. } \\
\text { content }\end{array}$} & True leaf & $32.60 \pm 1.13 \mathrm{a}$ & $31.91 \pm 1.40 \mathrm{a}$ & $31.76 \pm 1.17 \mathrm{a}$ \\
\hline & Scion cot. & $27.56 \pm 1.10 \mathrm{a}$ & $30.32 \pm 1.12 \mathrm{a}$ & $29.21 \pm 1.48 \mathrm{a}$ \\
\hline & Roots. cot. & $51.11 \pm 1.98 \mathrm{a}$ & $46.51 \pm 2.45 a$ & $50.16 \pm 2.98 a$ \\
\hline
\end{tabular}

$\mathrm{z}$ shoot dry weight-to-length ratio; DQI: Dickson's quality index; $\mathrm{F}_{\mathrm{v}} / \mathrm{F}_{\mathrm{m}}$ : maximum quantum yield of primary photochemistry of a dark-adapted leaf; ${ }^{y}$ Mean values $( \pm S E)(n=50)$, within a row, followed by different letters are significantly different $(P \leq 0.05)$ according to the results of the Scott-Knott method.

Table 5. Colorimetric parameters of grafted watermelon seedlings from two quality categories derived 14 days after grafting.

\begin{tabular}{ccccc}
\hline \multirow{2}{*}{ Plant Tissue } & Colorimetric Parameters & \multicolumn{3}{c}{ Quality Categories } \\
\cline { 2 - 4 } & & Optimum & Acceptable & Not Acceptable \\
\hline \multirow{3}{*}{ True leaves } & $\mathrm{L}^{* \mathrm{z}}$ & $40.00 \pm 0.46 \mathrm{a} \mathrm{y}$ & $41.26 \pm 0.49 \mathrm{a}$ & $41.30 \pm 0.53 \mathrm{a}$ \\
& $\mathrm{C}^{*}$ & $19.39 \pm 0.51 \mathrm{a}$ & $20.73 \pm 0.53 \mathrm{a}$ & $21.23 \pm 0.67 \mathrm{a}$ \\
& $\mathrm{h}^{\circ}$ & $129.40 \pm 0.42 \mathrm{~b}$ & $129.40 \pm 0.42 \mathrm{~b}$ & $128.56 \pm 0.48 \mathrm{~b}$ \\
& $\mathrm{a}^{*} / \mathrm{b}^{*}$ & $-0.86 \pm 0.01 \mathrm{~b}$ & $-0.83 \pm 0.01 \mathrm{a}$ & $-0.80 \pm 0.01 \mathrm{a}$ \\
\hline \multirow{3}{*}{ Scion cotyledons } & $\mathrm{L}^{*}$ & $44.70 \pm 0.47 \mathrm{a}$ & $43.87 \pm 0.42 \mathrm{a}$ & $44.89 \pm 0.39 \mathrm{a}$ \\
& $\mathrm{C}^{*}$ & $23.29 \pm 0.69 \mathrm{a}$ & $23.34 \pm 0.55 \mathrm{a}$ & $23.74 \pm 0.51 \mathrm{a}$ \\
& $\mathrm{h}^{\circ}$ & $126.54 \pm 0.41 \mathrm{a}$ & $126.35 \pm 0.37 \mathrm{a}$ & $126.20 \pm 0.30 \mathrm{a}$ \\
Rootstock & $\mathrm{a}^{*} / \mathrm{b}^{*}$ & $-0.74 \pm 0.01 \mathrm{as}$ & $-0.74 \pm 0.01 \mathrm{a}$ & $-0.73 \pm 0.01 \mathrm{a}$ \\
\hline cotyledons & $\mathrm{L}^{*}$ & $40.52 \pm 0.43 \mathrm{~b}$ & $41.92 \pm 0.43 \mathrm{a}$ & $42.53 \pm 0.59 \mathrm{a}$ \\
& $\mathrm{C}^{*}$ & $19.47 \pm 0.43 \mathrm{~b}$ & $20.92 \pm 0.46 \mathrm{a}$ & $22.10 \pm 0.71 \mathrm{a}$ \\
& $\mathrm{h}^{\circ}$ & $129.46 \pm 0.29 \mathrm{a}$ & $128.07 \pm 0.33 \mathrm{~b}$ & $127.82 \pm 0.40 \mathrm{~b}$ \\
& $\mathrm{a}^{*} / \mathrm{b}^{*}$ & $-0.82 \pm 0.01 \mathrm{~b}$ & $-0.79 \pm 0.01 \mathrm{a}$ & $-0.78 \pm 0.01 \mathrm{a}$ \\
\hline
\end{tabular}

${ }^{\mathrm{z}}$ lighting; $\mathrm{C}^{*}$ : chroma; $\mathrm{h}^{\circ}$ : hue angle; $\mathrm{a}^{*}$ : red/green coordinate; $\mathrm{b}^{*}$ : yellow/blue coordinate; ${ }^{\mathrm{y}}$ Mean values $( \pm \mathrm{SE})$ $(\mathrm{n}=50)$, within a row, followed by different letters are significantly different $(P \leq 0.05)$ according to the results of the Scott-Knott method.

\section{Discussion}

Seedling quality is one of the major concerns among farmers, and grafted watermelon seedlings are mainly produced by professional nurseries instead of individual farmers. Many factors influence quality evaluation and, therefore, it is difficult to define and categorize seedlings of different qualities. Seedlings of high-quality should have uniformity in terms of size and traits [3].

During healing, grafted seedlings remained in an environmentally controlled growth chamber where microclimate was almost identical for all seedlings. Nevertheless, two quality categories derived 7 days after grafting (i.e., after healing). The seedlings from both categories showed promising potential to develop into marketable plants of high quality. However, the days between the exit from the healing chamber and planting by the grower (i.e., between day 6 and day 14 after grafting) are crucial for maintaining high seedling quality. Many seedlings suffer during the period of acclimatization which might lead to quality deterioration [3]. In our study, three quality categories were developed at 14 days 
after grafting: two marketable categories (Optimum and Acceptable) and one non-marketable category (Not acceptable).

After 7 days, shoot height was highly distinguishable between the two quality categories, however, it was not confirmed after 14 days. Therefore, shoot height alone cannot be used as an efficient index of seedling quality before going to market. On the other hand, stem diameter was greater for Optimum seedlings at 14 days after grafting. Even though the differences were very slight and could not easily be detected by eye, this parameter is reliable for distinguishing the quality of grafted seedlings before going to market [13-15]. Color differences were not visually detectable, but colorimetry revealed slight distinctions at both times. However, relative chlorophyll content was similar at all measurement dates and quality categories. Additionally, no differences were detected between the quality categories in parameters such as leaf or cotyledon thickness and $\mathrm{F}_{\mathrm{v}} / \mathrm{F}_{\mathrm{m}}$, both seven and 14 days after grafting.

Seven days after grafting, one of the greatest morphological parameters that distinguished the Optimum and Acceptable seedlings was the area of true leaves, which leads to greater absorption of incident light in the first very important days of seedling development. Therefore, leaf area is a valuable indicator not only between marketable and not marketable seedlings, but also between the different quality categories of grafted watermelon.

As discussed above, Optimum seedlings were defined by faster leaf development, i.e., larger photosynthetic area in a shorter amount of time. Subsequently, this quality category contained seedlings with greater fresh and dry biomass production compared to the other categories, both 7 and 14 days after grafting, proving that these parameters can be used as index of marketable seedlings. Seven days is considered a short amount of time for grafted seedlings to develop a vigorous root system, especially when the original roots were completely removed, as in our case. However, the quality categories were also distinguished by root biomass.

$\mathrm{R} / \mathrm{S}$ ratio is a parameter related to the possibility of successful seedling establishment in the field which depends on the proper allocation of biomass between the above and below ground parts. Fourteen days after grafting, R/S ratio was greater for Optimum seedlings which developed a vigorous root system. Shoot DW/L ratio, which is a good indicator of seedling quality [3] revealed that Optimum plants were of higher value. Since this parameter was comprised of shoot dry weight and length (which is similar for the quality categories), biomass accumulation is decisive for the production of high quality seedlings at the nursery. DQI is commonly used for the evaluation of forest or fruit tree seedlings, but recently it has also been employed for assessing horticultural species such as cucumber, muskmelon and tomato [16-18]. Even though the parameter incorporates a number of destructive measurements, it is a useful indicator of seedling quality and plantation performance [19] since its values was correlated with the quality categories in our study.

Optimum seedlings have a better chance of developing into high quality marketable plants, with better establishment in the field, since they excelled in almost all tested parameters, including the essential leaf area and root dry weight. This superiority was also highlighted by shoot DW/L ratio and DQI. Acceptable seedlings were on the border between the other two categories. Parameters, such as stem diameter, shoot DW/L ratio, and DQI, were valuable for identifying them as marketable or not. Not acceptable seedlings after 14 days had inferior development with smaller leaves and considerably weaker root systems compared to the marketable seedlings. Their lower chance of successful establishment and slower development do not favor these seedlings as marketable.

It is concluded that leaf and cotyledon area of scion, stem diameter, shoot and root dry weights as well as shoot DW/L and DQI are good indicators for categorizing grafted watermelon seedlings. Specifically, seedlings of the highest quality must have a leaf area of about $25 \mathrm{~cm}^{2}$ and $50 \mathrm{~cm}^{2}$ at 7 and 14 days after grafting, respectively. Scion (watermelon cv. Celine) cotyledons must be fully expanded (about $15 \mathrm{~cm}^{2}$ ) 7 days after grafting, while rootstock cotyledons were not good indicators of seedling quality. Shoot height was a weak quality indicator 14 days after grafting, since Not acceptable values were similar to Optimum seedlings. However, stem diameter was a good quality index even though values between the categories were very close. Moreover, shoot and root dry weights, as well as shoot 
$\mathrm{DW} / \mathrm{L}$ ratio and DQI, proved valuable indicators of grafted watermelon seedling quality. The benefits of grafting is associated with the use of high quality watermelon seedlings, and their categorization could help both the nursery industry and growers.

Author Contributions: Conceptualization, methodology, and data analysis: F.B., A.K., A.S., and G.M.; experimental measurements: F.B., C.D. and D.K.; writing-original draft preparation: F.B. and A.K.; writing-review and editing: F.B., A.K, A.S., and G.M., supervision and project administration: A.K.

Funding: This research has been co-financed by the European Union and Greek national funds through the Operational Program Competitiveness, Entrepreneurship and Innovation, under the call RESEARCHCREATE-INNOVATE (project code: T1EDK-00960, LEDWAR.gr).

Conflicts of Interest: The authors declare no conflict of interest. The founding sponsors had no role in the design of the study; in the collection, analyses, or interpretation of data; in the writing of the manuscript; or in the decision to publish the results.

\section{References}

1. Lee, J.-M.; Bang, H.-J.; Ham, H.-S. Grafting of vegetables. J. Jpn. Soc. Hort. Sci. 1998, 67, 1098-1104. [CrossRef]

2. Davis, A.R.; Perkins-Veazie, P.; Hassell, R.; Levi, A.; King, S.R.; Zhang, X. Grafting Effects on Vegetable Quality. HortScience 2008, 43, 1670-1672. [CrossRef]

3. Lee, J.-M.; Kubota, C.; Tsao, S.J.; Bie, Z.; Hoyos Echevarria, P.; Morra, L.; Odag, M. Current status of vegetable grafting: Diffusion, grafting techniques, automation. Sci. Hortic. 2010, 127, 93-105. [CrossRef]

4. Louws, F.J.; Rivard, C.L.; Kubota, C. Grafting fruiting vegetables to manage soilborne pathogens, foliar pathogens, arthropods and weeds. Sci. Hortic. 2010, 127, 127-146. [CrossRef]

5. Savvas, D.; Colla, G.; Rouphael, Y.; Schwarz, D. Amelioration of heavy metal and nutrient stress in fruit vegetables by grafting. Sci. Hortic. 2010, 127, 156-161. [CrossRef]

6. Schwarz, D.; Rouphael, Y.; Colla, G.; Venema, J.H. Grafting as a tool to improve tolerance of vegetables to abiotic stresses: Thermal stress, water stress and organic pollutants. Sci. Hortic. 2010, 127, 162-171. [CrossRef]

7. Kyriacou, M.C.; Rouphael, Y.; Colla, G.; Zrenner, R.; Schwarz, D. Vegetable Grafting: The Implications of a Growing Agronomic Imperative for Vegetable Fruit Quality and Nutritive Value. Front. Plant Sci. 2017, 8, 741. [CrossRef] [PubMed]

8. Lee, S.G. Production of high quality vegetable seedling grafts. Acta Hortic. 2007, 759, 169-174. [CrossRef]

9. Lee, J.M.; Oda, M. Grafting of herbaceous vegetable and ornamental crops. In Horticultural Review; Janick, J., Ed.; John Wiley \& Sons: New York, NY, USA, 2003; pp. 61-124.

10. Dickson, A.; Leaf, A.L.; Hosner, J.F. Quality appraisal of white spruce and white pine seedling stock in nurseries. For. Chron. 1960, 36, 10-13. [CrossRef]

11. McGuire, R.G. Reporting of objective color measurements. HortScience 1992, 27, 1254-1255. [CrossRef]

12. Scott, A.J.; Knott, M. A Cluster analysis method for grouping means in the analysis of variance. Biometrics 1974, 30, 507-512. [CrossRef]

13. Mattsson, A. Predicting field performance using seedling quality assessment. New For. 1996, 13, 223-248.

14. Rawat, J.S.; Singh, T.P. Seedling indices of four tree species in nursery and their correlations with field growth in Tamil Nadu, India. Agrofor. Syst. 2000, 49, 289-300. [CrossRef]

15. Davis, A.S.; Jacobs, D.F. Quantifying root system quality of nursery seedlings and relationship to outplanting performance. New For. 2005, 30, 295-311. [CrossRef]

16. Guisolfi, L.P.; Lo Monaco, P.A.V.; Haddade, I.R.; Krause, M.R.; Meneghelli, L.A.M.; Almeida, K.M. Production of cucumber seedlings in alternative substrates with different compositions of agricultural residues. Rev. Caatinga 2018, 31, 791-797. [CrossRef]

17. Vendruscolo, E.P.; Campos, L.F.C.; Nascimento, L.M.; Seleguini, A. Quality of muskmelon seedlings treated with thiamine in pre-sowing and nutritional supplementation. Sci. Agrar. 2018, 19, 164-171. 
18. Costa, E.; Leal, P.A.M.; Benett, C.G.S.; Benett, K.S.S.; Salamene, L.C.P. Production of tomato seedlings using different substrates and trays in three protected environments. Eng. Agríc. 2012, 32, 822-830. [CrossRef]

19. Bayala, J.; Dianda, M.; Wilson, J.; Ouedraogo, S.J.; Sanon, K. Predicting field performance of five irrigated tree species using seedling quality assessment in Burkina Faso, West Africa. New For. 2009, 38, 309-322. [CrossRef] 